ment on the condition of a river is given by Turing cited by Hynes. "Fish are a very useful barometer of the real state of purity of a water. No river should be considered as in a satisfactory condition unless fish will live and thrive in it".

In short, the book sums up the work of the Water Pollution Research Laboratory, the Freshwater Biological Association and authorities in Europe and the United States, in a comprehensive and above all eminently readable way.

G. C. WARE

\section{NORTH AFRICAN PREHISTORY}

\section{The Stone Age in Northern Africa}

By C. B. M. McBurney. (Pelican Book No. A342.) Pp. $288+24$ plates. (Harmondsworth, Mddx. Penguin Books, Ltd., 1960.) $6 s$.

D. McBURNEY is among the half-dozen pre' historians who are really competent to write about the early prehistory of North Africa. Over a series of years he has visited much of the area and has himself made there important excavations. His book, therefore, can be confidently recommended to all students of the subject.

As a lecturer and teacher in the University of Cambridge who has travelled widely, he brings to bear on the problems of North Africa a wide know. ledge of prehistory elsewhere, and seeks to fit his special area into the pattern of the Stone Age world. Thus he begins his book with 60 pages on "The Present Stage of Prehistoric Studies"-a chapter which will be appreciated both by his less- and moreinstructed readers, and which presents the problem of North Africa in relation to the neighbouring areas of Europe, western Asia and Africa south of the Sahara. He then discusses the physical and climatic problems of his own region. Climatic changes in the past have profoundly affected the possibility of habitation during prehistoric times. Prior to the last pluvial period (Gamblian) the spine of the Sahara could be traversed from south to north, but afterwards such movements were, to say the least, difficult on account of the absolute desert conditions which set in.

Next come throe chapters which perhaps are the meat of the book and which deal, in order, with "The Earliest times of Man in North Africa", "The Middle Palæolithic" and "The Blade Industries and the Spread of Homo sapiens". In the first of these it is splendid to be given, with proper recognition of its importance, an account of the work of Arambourg and his finds of early Acheulean human remains at Ternifine (Palikao). To English readers such an account has not hitherto been readily available. Villafranchian faunal assemblages used as dategiving fossils are discussed and there are comparative faunal tables and some, perhaps not enough, text figures of varying excellence of some of the imple. ments found. In the Middle Palæolithic chapter the author has much excavated material to discuss and many problems, and can draw on the work of Miss Caton Thompson again and again. There is a charming account of his own finding of a hunter's encamp. ment site near the Wadi Derna in Cyrenaica, with a list of the animals eaten there, and where the typology of the finds brings to mind the industrial tradition of the lower Levalloiso-Mousterian of Palestine. In the "Blade Industries" chapter his own excavations have again helped the writer. The problems are more than ever complicated as he admits, but as a working hypothesis he offers a series of dates starting at 15,000 B.c. with the appearance of the earliest, Oranian in the Maghreb as a result of Gravettian influence or immigration from south-west Europe into a Levalloisean area until 5000 B.c., when the Upper Capsian seems to come to the end of its sway and Levantine influences are apparent. A final chapter on the Neolithic period, which gives a picture of a surprisingly uniform cattle-breeding (but sheepless and goatless) economy extending from the Atlantic. to the Nile, includes a short acccunt of less tran is pages of the North African rock-shelter art and about the same number of pages of illustrations. principally, I fancy, taken from Frobenius. On this matter, of course, a great deal more could be written. but the survey will be found useful to students. It is in a connexion like this that one must regret that owing to the economic problems of to-day such in fundamental study as this book could not have appeared in a larger format. So much which the author has touched on could have been usefully expanded. Nevertheless we now have, together with the complementary volumes in the series by Desmond Clark and Sonia Cole, three authoritative works on the prehistory of the continent of Africa.

M. C. BURKITT

\section{EXISTENTIAL PSYCHIATRY}

\section{The Divided Self}

A Study of Sanity and Madness. By Dr. R. D. Laing. Pp. 240. (London: Tavistock Publications, 1960.) 25s. net.

THIS book will be of interest to those who are orientated towards philosophy, but others may find it difficult going. The author is obviously widely read in existential and other modern philosophical theories and has attempted to apply them to understanding psychiatry --particularly schizoid personalities and schizophrenia.

The main weakness of the book is that it does not. develop a coherent $\mathrm{s}$; stem, but uses the existential ideas to explain some patients' symptoms without. giving a satisfactory scheme which is applicable in other cases. In some instances he sets up 'Aunt Sallies' only to knock them over. For example, he: complains that "the current technical vocabulary currently used splits up man verbally". By this presumably he means that one speaks of the ego. super-ego and id and so on. Yet this does not split up man verbally unless one regards an engineer who talks of the cylinder, piston, connecting rod and crank-shaft as splitting up an engine verbally. They are merely descriptive terms, and he still regards it as a whole engine.

The author puts forward a number of interesting mechanisms in schizophrenia, for example, engulfment, implosion, petrification, and depersonalization. $\mathrm{He}$ believes that the 'inner self' undergoes various changes in this disease and can be 'phantasicized' or. 'volatilized' ; it can become unreal, or impoverished, empty, dead, or split; it can be more and more charged with hatred, fear and envy.

The author complains that psychiatric theory has not changed since Kraepelin (although Freud changed a good deal), and perhaps he has laid the foundations of a systern which he may be able to develop further in other books.
CllFForn AlLEN 